\title{
Brand Equity and Perceived Value: The case in Commercial Banks in Sri Lanka
}

\author{
By
}

Yakupiti Mahendra Sandun Keerthipala

M.Sc. 


\title{
Brand Equity and Perceived Value: The case in Commercial Banks in Sri Lanka
}

\author{
By
}

Yakupiti Mahendra Sandun Keerthipala

A thesis submitted to the University of Sri Jayewardenepura in partial fulfillment of the requirements for the Degree of Master of Science in Management on $31^{\text {st }}$ January 2013 
The work described in this thesis was carried out by me under the supervision of Prof. Neville Warnakulasooriya and a report on this has not been submitted in whole or in part to any university or any other institution for another Degree/ Diploma.

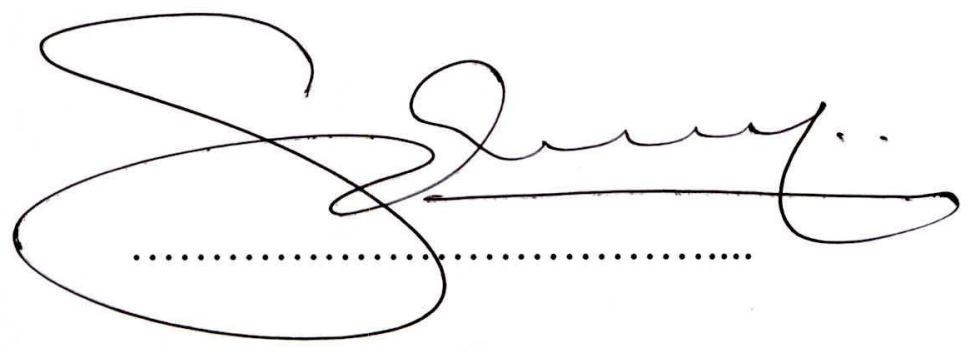

Y M Sandun Keerthipala

Date : 31st Jan. 2013

Student Registration No:5266FM2010 - 058 
I certify that the above statement made by the candidate is true and that this thesis is suitable for submission to the University for the purpose of evaluation.

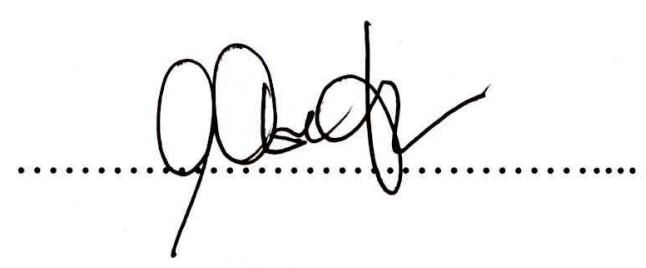

Prof. Neville Warnakulasooriya

Date : 31st Jan. 2013

Supervisor

$$
\begin{gathered}
\text { Dr, B. N. F. Warnakulasooriya } \\
\text { Senior Lecturer } \\
\text { Depatment of Marketing Managenent. } \\
\text { Universiyy of Sri Jayowardenepura, } \\
\text { Nugegoda }
\end{gathered}
$$




\section{ACKNOWLEDGMENT}

It has been a topsy-turvy journey of over two years enriched and embellished with an interesting, and at times difficult but always a highly pivotal patch of experience. I wish to express my humble gratitude to many great personalities who encouraged, supported, and sometimes prodded me along this path.

I would like to thank my supervisor Prof. Nevill Warnakulasooriya for giving me the brilliant idea of this study. My sincere appreciation extends to Prof K. D. Gunawardana and Dr P D Nimal who have been the main pillars of this highly successful and equally demanding Masters program, which they mentor successfully under many turbulent situations. I want to deeply thank Prof. H.H.D.N.P.K. Opatha, Dr. S.W Hirantha, Prof. T.M.B.Palawatta, Dr. S.T.W.S.Yapa, Mr.M.B.S.S.Udayanga, Mr.D.S.P Jayasooriya, Dr S.D.W.Jayawardena and the entire lecture panel, who guided me in my fundamental knowledge of research and other subject areas which have proven to be vital in both academic and professional encounters, and Dr. Janak Kumarasinghe whose sincere and warm trust always encouraged me, the support he extended going beyond his boundaries was a true blessing to my research.

With gratitude I would like to thank Dr Saman Dassanayake of The University of Colombo, 'The Black Swan' as he calls himself who's charm and of extensive knowledge, aids all of 
us to embosom the term 'Thesis' with sincere affection and enthusiasm. I pledge my sincere courtesy to Mr Jhonathan Alles (Chief Operating Officer at Hatton National Bank Ltd), Mr Dinuka L Perera (Head of Operations at Global Publishing Services - HSBC HDPL), Mr Kavinga Rajapakse (Director - DSI Samson Group of companies) and Mr Rohana Fernando (my first tutor in English / English Literature) for their support/guidance and the trust they kept on me.

My special appreciation to my wife Janani for her endless encouragement during times of difficulty, with love and understanding throughout this entire process. Thanks also go to my parents, my two brothers, parents-in-law and other family members including my four year old nephew and three year old niece for their unchanged trust in my endeavor.

I will not be able to leave out my two best friends at the MSc. program Chathu and Nadee, whose friendship and support have been one of the best finds/gains for me, during this program.

I am grateful to all the members of the Faculty of Management at The Sri Jayawardenapura University who taught me through this program and last but by no mean the least I would like to deliver my sincere appreciation to the non academic staff members at the MSc. unit who have been friendly, supportive and yet highly professional at all times.

This research is BECAUSE OF ALL OF YOU and FOR ALL OF YOU! 


\section{Table of Contents}

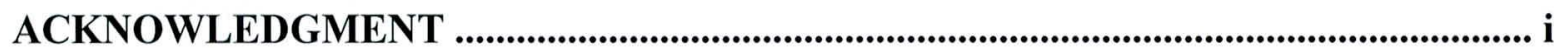

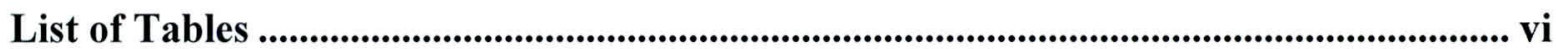

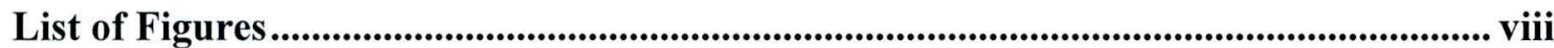

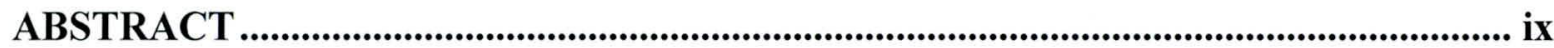

CHAPTER $1 \quad$ INTRODUCTION

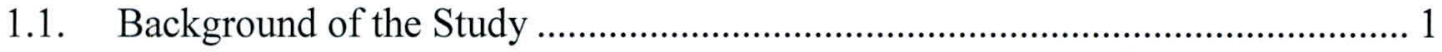

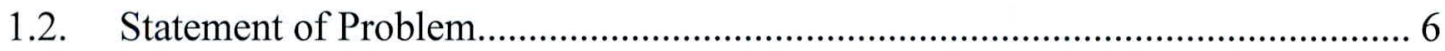

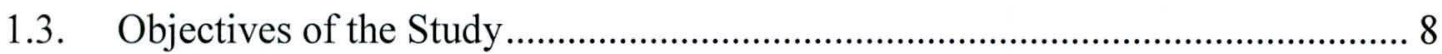

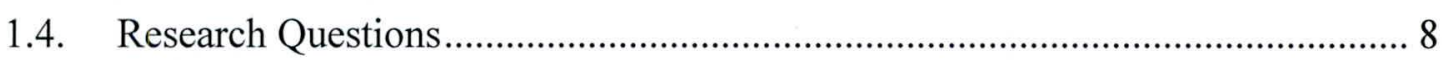

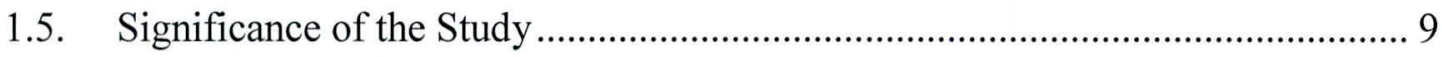

1.6. Boundaries/limitations of the Study .................................................................. 9

1.7. Organization of the Study ............................................................................. 10

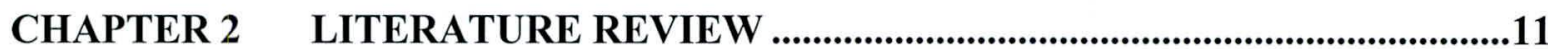

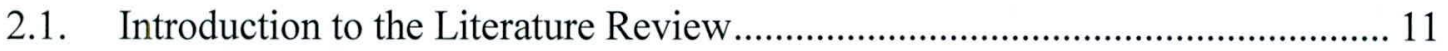

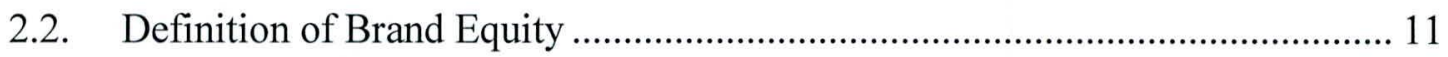

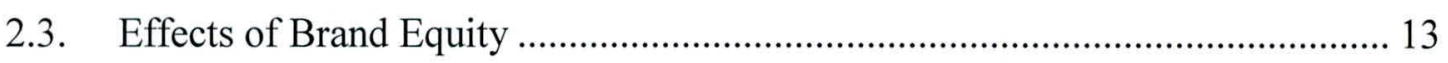

2.4. Importance of Brand Equity ......................................................................... 14

2.5. Dimensions Associated With Brand Equity .................................................... 16

2.6. Measurement of Brand Equity ......................................................................... 19

2.6.1. Measurement of Brand Equity - Financial Perspectives ................................. 29

2.6.2. Measurement of Brand Equity - Customer Perspectives ............................... 35

2.6.3. Measurement of Brand Equity - Combined Perspective................................ 44

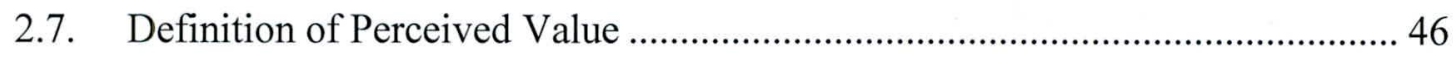

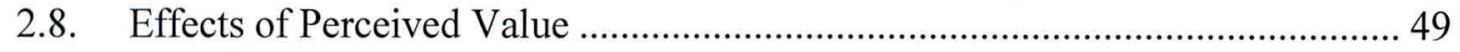

2.9. Importance of Perceived Value...................................................................... 50

2.10. Dimensions Associated with Perceived Value............................................... 51 
2.11. Measurement of Perceived Value …………………………………….......... 54

2.12. Brand Equity / Perceived Value Research in the Service Industry ................. 61

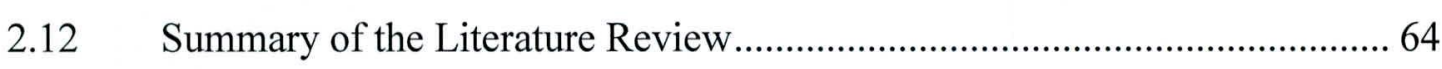

CHAPTER 3 METHODOLOGY ………………….........................................................70

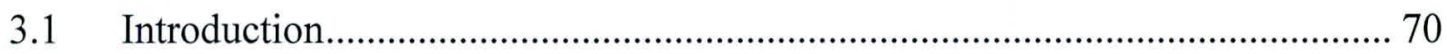

$3.2 \quad$ Theoretical Framework ………………………………………………...... 70

3.3 Conceptual Framework ..................................................................................... 74

3.3.1 Brand Equity Dimensions ...................................................................... 75

3.3.2 Perceived Value Dimensions ........................................................................ 79

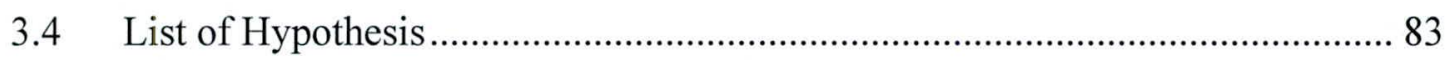

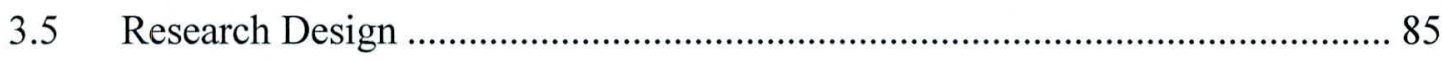

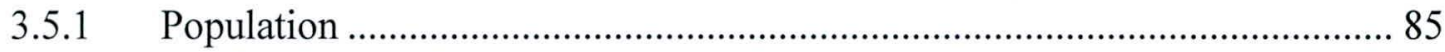

3.5.2 Sample

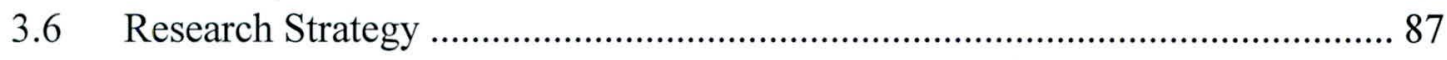

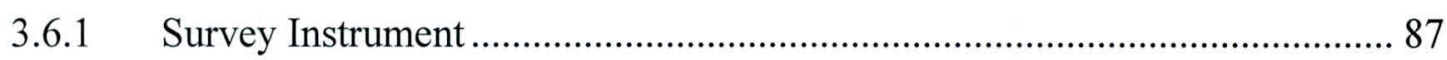

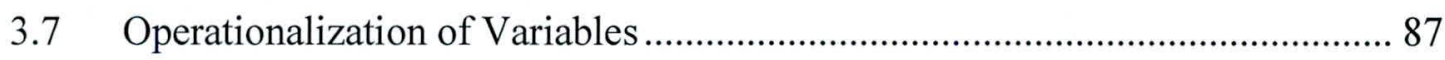

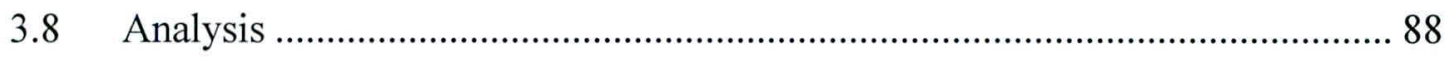

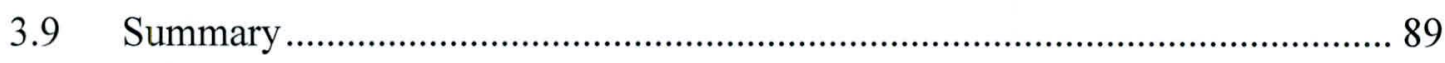

\section{CHAPTER 4 DATA ANALYSIS ...................................................................................90}

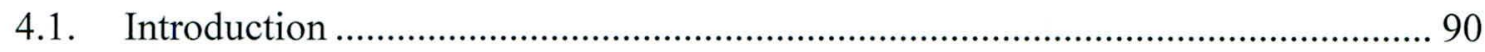

4.2. Sample Composition ..................................................................................... 90

4.3. Measurement of Reliability and Validity .......................................................... 92

4.3.1. Reliability Assessment ............................................................................... 92

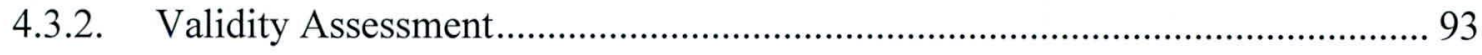

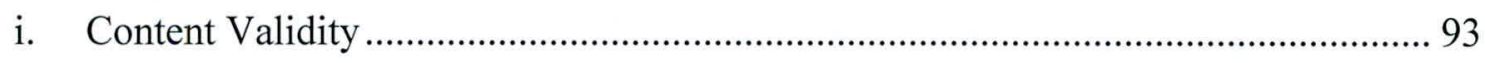

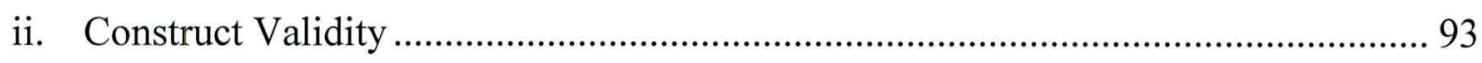


iii. Convergent Validity ........................................................................................ 94

iv. Discriminant Validity ...................................................................................... 100

4.4. Degree of Brand Equity ……………………………………………………... 103

4.5. Most Influential Dimension of Brand Equity ………………………………….... 108

4.6. Association between Brand Equity and Perceived Value ..................................... 113

4.7. Effect of Demographic Variables on the Brand Equity and Perceived Quality.. 117

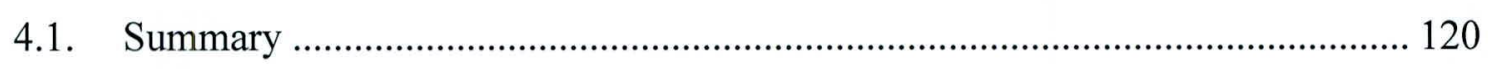

CHAPTER 5 DISCUSSION.................................................................................121

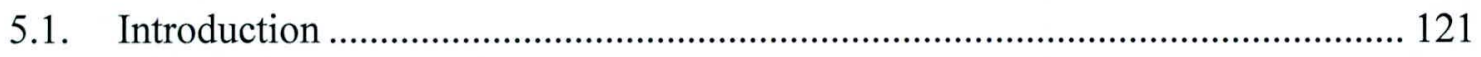

5.2. General Overview..................................................................................... 121

5.3. Degree of Brand Equity and Most Influential Dimension on Brand Equity ....... 123

5.4. Association between Perceived Value and Brand Equity .................................... 126

5.5. The Moderating Effect of Demographic Variables ............................................... 128

5.6. Areas for Further Studies .............................................................................. 129

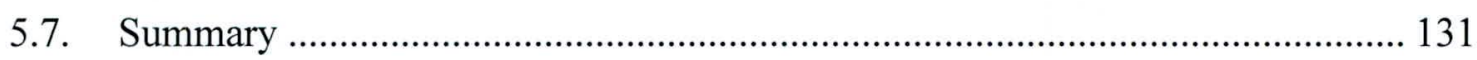

CHAPTER 6 SUMMARY AND CONCLUSION ……....................................................132

References .........................................................................................................................136

APPENDIXES ...................................................................................................................153 


\section{List of Tables}

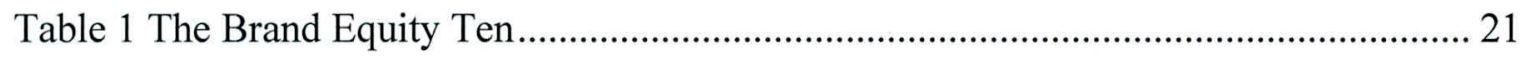

Table 2 Measure Used in Previous Studies on Consumer- Based Brand Equity................. 40

Table 3 A Measure of Expost Utilities of Brand ................................................................ 43

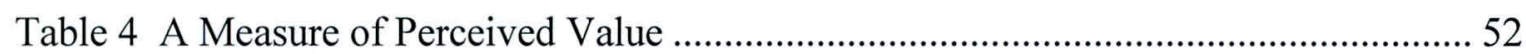

Table 5 Selected Articles of Previous Studies of the Multidimensionality of Perceived

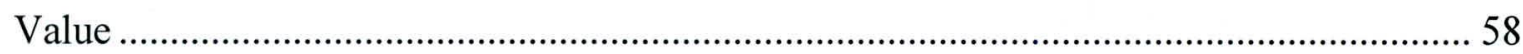

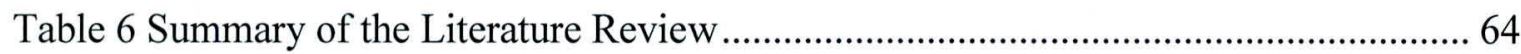

Table 7 Demographic Characteristics of Respondents ........................................................ 91

Table 8 Reliability Test - Cronbach's Alpha ............................................................... 93

Table 9 Rotated Factor Matrix for Brand Equity ........................................................... 95

Table 10 Average Variance Extracted (AVE) - Convergent test for Brand Equity ............. 96

Table 11 Convergent Validity Test Results for Individual Components of Brand Equity .. 97

Table 12 Rotated Factor Matrixes for Perceived Quality ................................................ 99

Table 13 Average Variance Extracted (AVE) - Convergent test for Perceived Quality ..... 99

Table 14 Convergent Validity Test Results for Individual Components of Perceived Quality 100

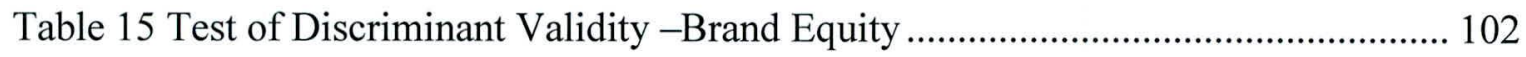

Table 16 Test of Discriminant Validity -Perceived Value ............................................. 103

Table 17 Degree of Brand Equity/Dimensions of Brand Equity ..................................... 104

Table 18 Bank wise Degree of Brand Equity/Dimensions of Brand Equity..................... 106 
Table 19 Omnibus Tests of Model Coefficients ............................................................. 108

Table 20 Cox \& Snell R Square \& Nagelkerke R Square............................................... 109

Table 21 Predicted Values of Dependent Variable ...................................................... 110

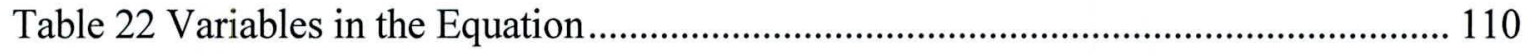

Table 23 Correlation Matrix for dimensions of brand equity and perceived value ........... 114

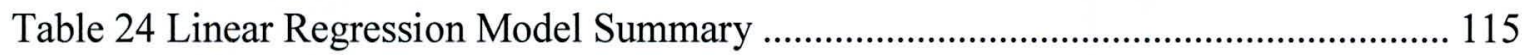

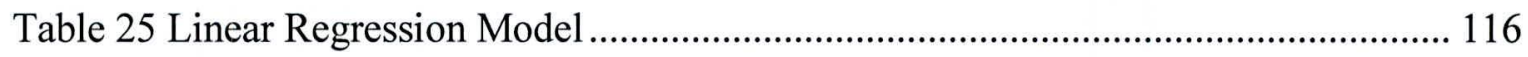

Table 26 Linear Regression Model Summary with Dummy Variables ............................. 118

Table 27 Linear Regression Model with Demographic Variables.................................... 118

Table 28 Estimated Means with Effect from Dummy Variables .................................... 120 


\section{List of Figures}

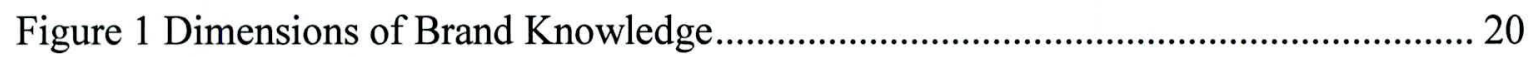

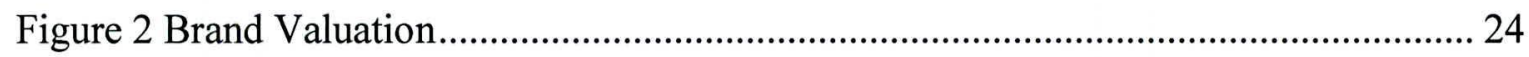

Figure 3 Brand Equity Measurement with the Brand Asset Valuator (BAV) ..................... 27

Figure 4 Global Brand Equity Valuation Model.......................................................... 45

Figure 5 Customer Experience and Value-In-Use ........................................................ 55

Figure 6 Dimensions of Customer Perceived Value ….................................................... 57

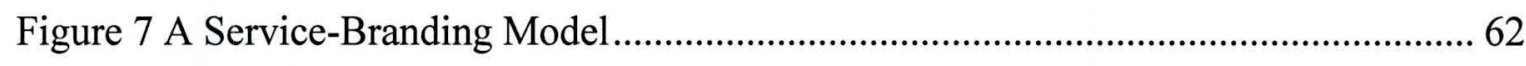

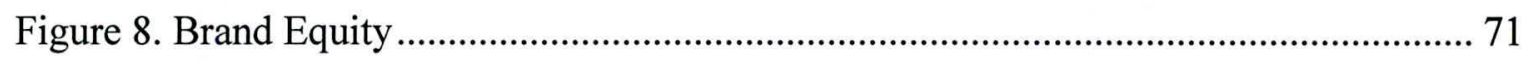

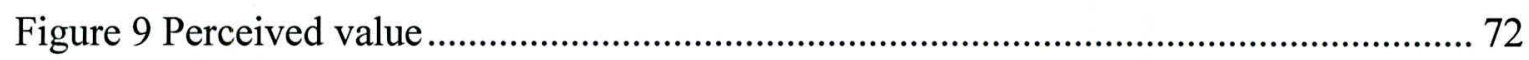

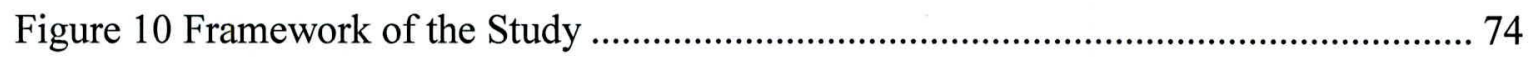




\title{
Brand Equity and Perceived Value in the Case in Commercial Banks
}

\author{
in Sri Lanka
}

\section{Yakupiti Mahendra Sandun Keerthipala}

\begin{abstract}
In the midst of Economic upheaval that we are faced globally, time could have not been more crucial to critically discuss the impact of Brand Equity and Perceived Value in the sector of Commercial Banks in Sri Lanka. Where more than two third of the world economy is accountable under the Service sector, effective brand management, through understanding of 'Brand' and 'Brand Equity' thus 'Perceived Value' could be the deciding or the winning factor, which would essentially differentiate one service provider from another.
\end{abstract}

The main objectives of this study is to underpin the degree of Brand Equity, to identify the most influential dimension of Brand Equity, to evaluate the association/relation between Brand Equity and Perceived Value and to determine the moderating effect on demographic factors on the association between Brand Equity and Perceived Value. To find answers to these objectives/research questions with empirical evidence, this research was carried out, taking into consideration various factors such as the sample size, validity of the collected data, limitations of the study. 
Six commercial banks in Sri Lanka have been considered as the sample of the study namely, Bank of Ceylon, Peoples Bank, Hatton National Bank, Commercial Bank, Sampath Bank and Seylan Bank. 413 respondents were considered covering all banks in sample. The research strategy to collect data was a survey questionnaire, which was validated using content and construct validity tests.

Findings of this study indicate a moderate degree of Brand Equity in the Commercial Banking sector in Sri Lanka, in sector wise this stands the same with a slight positivity towards the private banking sector where the degree of Brand Equity tends to be comparatively high. Perceived Quality was the most influential dimension of the degree of Brand Equity. There was a higher degree of association between Brand Association and Perceived Value, where the quick identity and established perception of a Brand tend to pay off in terms of Perceived Value, which also hinder the uncertainty in purchasing/consuming a product/service, which may be a reason for aggressive and assertive marketing exercises practiced by many financial institutes and service sector related organizations. Finally the moderating effect of Demographic Variables is proven to be null in relation/association between Brand Equity and Perceived Value.

In conclusion the importance of Brand equity and Perceived Value gain its importance day by day, and modern day managers should adopt and execute a holistic approach towards building and maintaining Brand Equity and Perceived Value, which will ultimately answer the final question 'To be or not to be' (Hamlette, Shakespeare) successful in terms of prolonged success and continues progression. 


\section{CHAPTER 1 \\ INTRODUCTION}

\subsection{Background of the Study}

Over the past few decades, there has been an explosive interest in brands among practitioners and researchers. The notion that a brand has an equity that exceeds its conventional asset value was developed by financial professionals (Motameni et al. 1998). According to Cobb-Walgren (1995), the probability of failure of a new brand launching in the market is as enormous as the cost of bringing new brand to market. Due to brands' special attributes contributing to firms' assets, bank/financial institute brands are regarded as very important properties that add significant value to the firms. Thus, many banks/financial institutes are looking for expansion opportunities to acquire existing brands rather than to develop new brands. This has been the trend in this sector globally since the traceable history, for an example locally, in 1970 Hatton bank acquired the branches of National Grindlays Bank in Kandy and Nuwara Eliya, heralding the change of name to Hatton National Bank in which went on to acquire Colombo branch of Emirates International Bank UAE in 1989 and Habib Bank AG Zurich in 2002. In the global history National Provincial Bank (est.1833) and Westminster Bank (est.1836), merged as National Westminster Bank in 1970. Giving a considerable weight to the economic climate and other influential factors for these mergers and acquisitions, still the notion to which Brand, Brand equity and perceived value have gained its limelight, being deciding/curtail factors of these mergers/acquisitions cannot be shaded or ignored. 